\title{
Klimaat in de kluts: tegenstrijdigheden in Rotterdams klimaatbeleid*
}

\author{
Helen Stout
}

\section{$1 \quad$ Inleiding}

Gemeenten staan de komende jaren voor grote uitdagingen. Niet in de laatste plaats doordat de rijksoverheid de afgelopen jaren een aantal belangrijke publieke taken naar het lokaal bestuur heeft overgeheveld. Denk bijvoorbeeld aan de Wet maatschappelijke ondersteuning, op basis waarvan gemeenten verantwoordelijk zijn voor de ondersteuning van mensen die niet op eigen kracht zelfredzaam zijn, of aan de jeugdhulpverlening, die sinds 2015 tot de verantwoordelijkheid van de gemeente behoort op grond van de Jeugdwet. Deze nieuwe opdrachten komen boven op reeds bestaande taken, voortvloeiende uit de verplichting om wetten en regelingen van het Rijk uit te voeren (medebewind). Voorbeelden hiervan zijn de Participatiewet, waarin (onder meer) de Wet werk en bijstand is opgegaan en de Wet houdende regels over het beschermen en benutten van de fysieke leefomgeving, beter bekend onder de naam Omgevingswet. Voor de toekomst staat ook het nodige op stapel. De afspraken van het Klimaatakkoord van Parijs komen er ook voor gemeenten aan.

Hoewel niet met zoveel woorden in de nieuwe Klimaatwet vastgelegd (op een algemeen geformuleerde overlegverplichting in art. 8 lid $1 \mathrm{na}$ ), kan wel worden geconcludeerd dat gemeenten een belangrijke rol zullen spelen in de uitvoering van het beleid, gericht op het terugdringen van de emissies van broeikasgassen, dat nu in de maak is. Hoe anders woonhuizen te verduurzamen of het aantal aardgasaansluitingen terug te dringen naar de uiteindelijk gewenste situatie dat niemand meer met aardgas zijn of haar huis verwarmt of kookt? De Klimaatwet bruist van de ambities. Maar heel veel verder dan dat zijn we nog niet. De uitwerking van de nieuwe wet laat nog op zich wachten.

Dat heeft een aantal gemeenten er niet van weerhouden om aan de slag te gaan. Sommige zijn al jaren bezig. Zo heeft de gemeente Rotterdam al in 2007 het 'Rotterdam Climate Initiative' gelanceerd met het doel de $\mathrm{CO}_{2}$-uitstoot in 2025 met de helft te reduceren. Tegen deze achtergrond speelt de kwestie van de overslag van steenkool in de Rotterdamse haven zich af, die hier nader wordt besproken. Volgens menigeen een schoolvoorbeeld van een overheid 'die met de ene hand neemt wat zij met de andere geeft'. Met andere woorden: een illustratie

* Deze redactionele bijdrage schreef Helen Stout ter gelegenheid van haar afscheid (ze was redactielid tussen 1998 en 2020) van de redactie van Bestuurswetenschappen. 
van tegenstrijdig beleid in een lokale situatie. De vraag werpt zich op waardoor deze tegenstrijdigheid kon ontstaan en wat eraan kan worden gedaan om botsingen in de toekomst te voorkomen.

\section{Casus kolenoverslag}

\section{Verlenging erfpacht}

Rotterdam is al geruime tijd de belangrijkste Europese doorvoerhaven voor steenkool, een fossiele brandstof die zeer gewild is in de 'oude' economie. In 2016 bedroeg de totale kolenoverslag 28,4 miljoen ton, ongeveer zes procent van de totale overslag in de haven. Vanwege de ernstige milieuvervuiling die met de verwerking ervan gepaard gaat, alsook het gegeven dat het om brandstof gaat die niet hernieuwbaar is en de aarde uitput, is steenkool en het gebruik daarvan omstreden.

In 1993 heeft het Rotterdamse havenbedrijf een perceel grond in erfpacht gegeven aan Europees Massagoed Overslagbedrijf BV (EMO) voor de op- en overslag van steenkool. EMO is een grote terminal voor kolen en ijzererts. Op 30 juni 2018 liep de erfpachtovereenkomst, die een looptijd van 25 jaar had, tussen het havenbedrijf en EMO af. In de erfpachtvoorwaarden is opgenomen dat de duur van de erfpacht na afloop van de termijn door de erfpachter (lees: EMO) eenzijdig kan worden verlengd met nog een termijn van 25 jaar. Alleen de hoogte van de canon, het tarief, vormt onderwerp van nieuwe onderhandeling en behoeft de instemming van beide partijen. Toen EMO eind 2017 het voornemen tot verlenging kenbaar maakte, ontstond grote beroering. Een groep natuurorganisaties riep de Rotterdamse gemeenteraad op om het contract met EMO niet te verlengen. De raad gaf gehoor aan de oproep. Op 14 november 2017 nam de gemeenteraad een motie aan waarin werd opgeroepen een plan te maken voor een snelle afbouw van de kolenoverslag. Rotterdamse raadsleden uitten hun misnoegen over de geplande verlenging. Er was onbegrip. Hoe kon het havenbedrijf doorgaan met steenkool terwijl is afgesproken dat de haven in $2050 \mathrm{CO}_{2}$-neutraal moet zijn?

Het havenbedrijf schoot publiekelijk in de verdediging. Dat dit soort contracten een lange looptijd hebben is niet ongewoon, evenmin de clausule van eenzijdige verlenging. Er bestaat behoefte aan continuïteit bij de overslagbedrijven, zodat zij langlopende afspraken met afnemers kunnen maken en investeringen kunnen plegen voor de lange termijn, hetgeen in de sector van vitaal belang is. Bovendien zal het stoppen van de kolenoverslag in Rotterdam nauwelijks effect hebben op de $\mathrm{CO}_{2}$-uitstoot, aangezien naburige havens de plaats van Rotterdam als overslagpunt zullen overnemen nu de vraag naar steenkool, voornamelijk uit Duitsland, onverkort groot blijft. Een en ander laat onverlet de meer principiële kwestie dat niet de gemeente maar Havenbedrijf Rotterdam NV als beheerder, exploitant en ontwikkelaar van het Rotterdamse haven- en industriegebied over individuele gronduitgiften en contracten gaat, zo betoogde het havenbedrijf. 


\section{Regie uit handen gegeven?}

Dat laatste punt snijdt zeker hout. Het havenbedrijf was oorspronkelijk een gemeentelijke dienst, het Gemeentelijk Havenbedrijf Rotterdam (GHR). Als GHR legde het havenbedrijf verantwoording af aan het gemeentebestuur. De gemeenteraad benoemde de algemeen directeur van het havenbedrijf, die bevoegdheden uitoefende op basis van mandaat. Voorgenomen besluiten werden aan het gemeentebestuur voorgelegd, waardoor integrale afweging van betrokken publieke belangen mogelijk was. Het GHR was in zijn handelen gebonden aan de begroting van de gemeente en de door haar verwoorde beleidsdoelstellingen. Het havenbedrijf gaf namens de gemeente bedrijfsterreinen uit aan bedrijven op basis van huur of erfpacht. De gemeente als privaatrechtelijke rechtspersoon was in die gevallen contractspartner.

Onder invloed van het modieuze New Public Management-denken werd per 1 januari 2004 de dienst GHR verzelfstandigd en omgevormd tot een naamloze vennootschap, waarvan op dit moment de gemeente Rotterdam (70,8 procent) en de Staat (29,2 procent) aandeelhouder zijn. Vergroting van de doelmatigheid en verhoging van de slagkracht, dat waren de verwachtingen die men bij de omvorming had. Daarmee verdween de gemeente uit beeld. De rechtspersoon Havenbedrijf Rotterdam NV kon voortaan zelfstandig juridisch opereren. Niet langer was het gemeentelijk beleidskader leidend. Bij een vennootschap staan (kort door de bocht) het commercieel belang en de continuïteit van de onderneming voorop. De handelingsruimte van en de verhoudingen tussen de organen van een vennootschap worden, behalve door de dwingendrechtelijke bepalingen uit het Burgerlijk Wetboek, bepaald door de statuten. Een en ander komt erop neer dat het gemeentebestuur weinig in de melk te brokkelen heeft waar het gaat om de bedrijfsvoering door Havenbedrijf Rotterdam NV. Van gemeentelijk beleid hoeft het havenbedrijf zich niets aan te trekken en dat is 'm nou net waar de schoen wringt. Er vindt niet langer een integrale afweging van betrokken belangen plaats. Het havenbedrijf heeft alleen oog voor de havenbelangen (en moet dat op grond van de geldende statuten ook doen!), de gemeente heeft 'alle andere' publieke belangen in portefeuille en moet maar zien hoe zij die beschermt met het haar ter beschikking staande instrumentarium. In de kwestie van de erfpachtverlenging heeft het havenbedrijf gewoon doorgezet, de gemeenteraad en klimaatactivisten met lege handen achterlatend.

\section{Klimaatbeleid in de Rijnmond naar de knoppen?}

Waar de gemeente nog vol goede moed in 2007 het 'Rotterdam Climate Initiative' lanceerde met het doel de $\mathrm{CO}_{2}$-uitstoot in 2025 met de helft te reduceren, doen recente cijfers het ergste vrezen. Naar ramingen van het $\mathrm{CBS}$ is de $\mathrm{CO}_{2}$-uitstoot in de Rijnmond van 24 megaton in 1990 naar 34 megaton in 2016 gestegen. Inmiddels is Rotterdam verantwoordelijk voor twintig procent van de gehele Nederlandse $\mathrm{CO}_{2}$-uitstoot. Daarvan kan weer negentig procent op conto van de haven 
worden geschreven. Als we op deze voet doorgaan met de uitstoot van broeikasgassen, is Rotterdam in 2030 een van de meest vervuilende Europese kuststeden. Hoe verhoudt deze ontwikkeling zich met het gemeentelijk beleid en de klimaatafspraken van Parijs op basis waarvan de economie in 2050 nagenoeg $\mathrm{CO}_{2}$-neutraal moet zijn?

Het havenbedrijf speelt een cruciale rol bij het behalen van de klimaatdoelstellingen door de gemeente Rotterdam, zoveel is duidelijk. Maar wat als het havenbedrijf andere prioriteiten heeft? Bijvoorbeeld geld verdienen aan de klimaat ontwrichtende fossiele-energie-industrie. Dat Havenbedrijf Rotterdam NV in 2006 de oprichtingsstatuten heeft gewijzigd en de doelstelling om bij te dragen aan 'het woon-, werk- en leefklimaat van de stad en regio Rotterdam, ook indien deze activiteiten voor de vennootschap (aanvankelijk) verliesgevend zijn' heeft geschrapt, is niet bemoedigend. Evenmin de in de recente jaarverslagen opgenomen 'opdracht om op lange termijn de economische waarde van het haven- en industriecomplex te waarborgen'.

In 2015 en 2016 werden op de Maasvlakte twee gloednieuwe kolencentrales in gebruik genomen. Het havenbedrijf was de trotse gastheer, ondanks het feit dat de bouw van de centrales van het begin af aan omstreden was vanwege hun bijdrage aan klimaatverandering. Het Duitse E.ON, inmiddels omgedoopt tot Uniper Benelux, is eigenaar van Maasvlakte Power Plant 3 (MPP3) met een capaciteit van 1070 megawatt. Deze centrale, die in 2016 in gebruik is genomen, kan naast steenkool ook biomassa verstoken, dit laatste met een maximum van twintig procent. Voor de bouw van deze centrale op de Tweede Maasvlakte heeft de overheid subsidie verstrekt voor een bedrag van twee miljard euro, uitgesmeerd over een periode van tien jaar. De totale investering voor de centrale bedroeg 1,7 miljard euro. De tweede Rotterdamse kolencentrale, de Engie Centrale Rotterdam, heeft een vermogen van 731 megawatt en bevindt zich op de Eerste Maasvlakte. De Franse gigant en multi-utility GDF SUEZ was, in samenwerking met het Belgische Electrabel, opdrachtgever. In 2017 gaf Engie, de naam waaronder de exploitant verder ging, te kennen af te willen van de kolencentrale. Plannen om de centrale om te bouwen en over te laten schakelen op de verwerking van biomassa of reststromen uit de industrie liepen op niets uit. Te riskant. Te kostbaar en met naar verwachting slechts een geringe milieuwinst. Het Amerikaanse investeringsfonds Riverstone Holding LLC is sinds kort de nieuwe eigenaar. Voor het klimaat valt het ergste te vrezen. Amerikaanse investeringsfondsen hebben geen goede naam waar het om de bescherming van 'zachte' maatschappelijke belangen gaat. Deze fondsen worden doorgaans geleid door high profits op korte termijn.

De twee kolencentrales staan nu in de landelijke top tien van $\mathrm{CO}_{2}$-uitstoters. Hun $\mathrm{CO}_{2}$ wordt niet afgevangen, maar gaat vrijelijk de schoorsteen uit. Samen met de nieuw gebouwde Eemscentrale in Groningen betekenen de centrales een enorme stap terug in het streven de $\mathrm{CO}_{2}$-uitstoot in Nederland te reduceren. 


\section{Institutionele verankering van publieke belangen}

De mislukte interventiepoging van de raad in de kwestie van de erfpachtverlenging illustreert de machteloosheid van de gemeente. Zij laat tevens zien dat het algemene gevoelen toch is dat het havenbedrijf geen 'gewoon' bedrijf is, zoals bijvoorbeeld Shell, Philips of Unilever. Het havenbedrijf heeft omwille van het optimaal behartigen van het algemene belang gemoeid met de haven, van de gemeente het monopolie gekregen op de exploitatie en beheer van de haven. Uiteindelijk komt de bestaansreden van het havenbedrijf uit publieke en niet uit private bron. Dat kan niet worden ontkend, ondanks de verhullende privaatrechtelijke rechtsvorm. Havenbedrijf Rotterdam NV is, met andere woorden, een hybride organisatie. Om die reden is het zaak om ervoor te zorgen dat die publieke dimensie opnieuw in het havenbedrijf wordt ingebracht. Nu is het zo dat er voor het havenbedrijf als het ware een perverse incentive bestaat om de inkomsten uit huur of onder erfpacht uitgegeven bedrijfsterreinen te optimaliseren onder verwaarlozing van andere betrokken publieke belangen. Inkomsten uit contracten (o.a. huur, erfpacht en kadegelden) vormen het enige element in het verdienmodel van het havenbedrijf, dat geen andere bronnen van inkomsten heeft.

Door de verzelfstandiging in 2004 is de behartiging van publieke belangen niet meer belegd in het havenbedrijf, maar 'erbuiten', bij andere entiteiten zoals gemeente, provincie en dergelijke. De vraag werpt zich op hoe ook andere belangen dan economische in de afweging van het havenbedrijf kunnen worden betrokken, ervan uitgaande dat terugdraaien van de verzelfstandiging geen optie is.

Het constitutionele framework voor de institutionele structuur wordt gevormd door de statuten van de vennootschap. In Boek 2 van het BW zijn regels met betrekking tot de statuten van rechtspersonen in het algemeen en die van de naamloze vennootschap in het bijzonder opgenomen, in een mix van dwingend, aanvullend en regelend recht. Geheel indachtig de wens om tot een vermenging van het publiek- en privaatrecht te komen zou de Algemene wet bestuursrecht (Awb) aanvullend op het BW dwingende regels kunnen stellen met betrekking tot de inhoud van de statuten. Denk bijvoorbeeld aan de verplichting om de statutaire doelstellingen te verruimen met alle betrokken publieke belangen. Met behulp van eenvoudige schakelbepalingen kan vervolgens artikel 3:4 van de Awb worden geïncorporeerd in het regelbestand waaraan de vennootschap zich heeft te houden. Artikel 3:4 van de Awb is een codificatie van de tot het zorgvuldigheidsbeginsel behorende norm, dat een organisatie de verschillende bij een besluit betrokken belangen bij haar besluitvorming moet betrekken.

Overigens zou de Awb via eisen te stellen aan de inhoud van statuten tevens publiekrechtelijke waarborgen kunnen introduceren in de privaatrechtelijke context waarbinnen de vennootschap opereert. Te denken valt bijvoorbeeld aan een regeling van inspraak en rechtsbescherming. Op die manier zou het mes aan twee kanten kunnen snijden. Aan de publieke belangen zou een goede dienst worden bewezen en de neuzen van havenbedrijf en gemeente zouden voortaan in dezelfde richting wijzen. 